\section{WILLIAM STANLEY JEVONS}

WILLIAM STANLEY JEVONS, whose tragical death was recorded in our issue of the 17 th inst., (p. 377), was born at Liverpool in 1835. As in the case of most men of intellectual work, the facts of his life are few and simple. He was educated partly in Liverpool, partly at University College, London, where he particularly distinguished himself in the classes of mathematics and natural science. For University College Jevons ever retained feelings of the warmest loyalty. He was proud of his connection with it and with the London University, and doubtless these feelings weighed with him when in 1876 he resigned his chair at the Owens College and accepted that of Political Economy at University College. Before completing his career as a student, Jevons accepted an appointment in the Sydney Mint and spent five years (1854-59) in practical work abroad. At the close of that time his disinterested determination to devote his life and energies to intellectual work of the highest kind prompted him to return to England and to resume his interrupted studies. He graduated at London in 1862 with the highest distinction in logic and political economy, and a year later began his active career as a teacher in the capacity of general teacher at the Owens College, a post he occupied for three years. Even at this early period of his life, however, he had already produced not only an earnest of his great powers but the germs of all the best work he afterwards accomplished. A pamphlet on the Fall in the Value of Gold, and an important work on the probability and consequences of the exhaustion of coal sufficiently attested his mastery over concrete problems of economics. But of even greater significance was the short paper presented in 1862 to the British Association on quantitative reasoning in economical theory and the little noticed volume on Pure Logic (1864). The one contains the fundamental notions of the author's later work in theoretical political economy, the other the first principles and outlines of the development of his wellknown symbolical logic. In I 866 Jevons was appointed to the combined chair of Philosophy and Political Economy at the Owens College, and for ten years he discharged with the greatest ability and success the onerous duties of the office. During this time his practical activity was incessant and his intellectual labour continuous. In political economy his occasional contributions in the shape of papers in the Statistical Society's Tournal, addresses or reviews, his important treatise, the Theory of Political Economy (I871), and his excellent manual on logic, his tract Money; or, The Substitution of Similars, his Elementary Lessons on Logic, and his great work, the Principles of Science (1874), raised his reputation to the highest point, and it may be confidently said that no man ever obtained or deserved so thoroughly to obtain more widespread recognition as a master in these departments of knowledge. In 1876 the feeling that his time might with greater advantage to himself and the public be devoted to continuing his original researches, prompted his resignation of the laborious chair at Owens College. In that year he migrated to London and to University College, and for five years he continued to hold the chair of Political Economy in that institution. The same desire for more time induced him in $\mathrm{I} 88 \mathrm{I}$ to resign the comparatively light duties of his London chair, and he was doubtless enjoying the feeling of perfect freedom to devote himself to his beloved work when the abhorred shears cut short the thin spun thread of his life. A great force for good and a noble type of the man of science has been lost to us in Jevons.

The feature which perhaps impresses one most in reviewing the products of so busy a life, apart altogether from the fine and most lovable character of the man, is the combination of multifarious interests with uncommon tenacity in working out certain definite lines of thought.
It is a feature peculiar to what is called genius and its presence, even when in less than a pre-eminent degree stamps the mind, exhibiting it as one of the highest order. Jevons's scientific training was excellent, his knowledge of the details of scientific work in many diverse branches truly universal, his interest in scientific questions and his love of scientific research of the keenest. A full record of the many contributions made by him to the great dictionary for the library of Chemistry and Philosophical Society in Manchester, to the Philosophical Magazine, and to our columns, it is hardly possible yet to produce, but it may be said that the character of his work, whether it be upon gold assaying, upon the forms of clouds, upon the motion of minute particles in liquids (a phenomenon named by him pedesis and examined with long continued and loving care), or upon the connection of sun-spot periods with economic changes, is such as to prove him amply endowed with the finest qualities of the investigator of nature. Indeed there can be little doubt that had Jevons devoted himself to physical inquiry he had all the ability to secure a refutation possibly not inferior to that gained by him in other departments. He was an exact thinker, in the best sense of that term, and brought to bear upon great and economical problems a power of methodical, patient reflection comparable with that displayed by any of his contemporaries in the field of physical research.

In logic and political economy his numerous and varied writings have secured him a very distinct place in the first rank of writers. In both subjects he united, to a quite unusual extent, wide and comprehensive knowledge of detalls, with rare originality in handling scientific principles. His treatment of questions of detail, apart from his original contributions to the thecry of either subject, would alone have secured for him a high reputation. Thus the Principles of Science contains a most exhaustive and penetrating analysis of the methods of scientific work, illustrated from all branches of scientific research with a fulness and precision that leave little to be desired, while his various works and papers on economic and social problems, in the treatment of which he exhibited a most happy talent of effective exposition, constitute a contribution of very high value to the literature of political economy.

The fermanence of his fame as a writer of the first order in his special subjects, however, must naturally depend upon the character and value of his original researches in the first principles of logic and political economy. As was above said these researches occupied Jevons throughout the whole of his active career as a writer, and his successive works are but the amplification and development of thoughts which had presented themselves to his mind at a very early period of his life. In political economy this thought was the reference of the laws of complex phenomena, such as prices, interest, and so on, to the simpler laws of pleasurable and painful feeling, the subjection of their simpler laws to quantitative treatment and the consequent application of exact, even of mathematical, methods to economi s. He was too farseeing and too judicious to overlook the enormous gulf that separates abstract economies from the domain of practice, ard he was under no delusion as to the practicability of applying exact methods to phenomena so immensely complex as those of society, but within the domain of abstract theory he perceived the need for some more vigorous method than that usually employed, and his contribution is of rare value. Here indeed, as in logic, Jevons had to suffer a fate common to thinkers of undoubted originality, that of discovering that their new principles and new methods are not absolutely new. But in either science, it may be safely said that if Jevons's contributions cannot claim novelty, they can always claim originality in the honest sense. They were thoroughly his own and were developed by him with ingenuity and 
exhaustiveness such as amply to establish his title to them. No man, it may be added, was ever more anxious than Jevons to do justice to the labours of his predecessors, and he was ever ready to welcome in the most generous fashion any indication of an anticipation of some favourite thought. His work was good enough, and he knew it was good enough, to stand upon its own merits.

In logic the system of formal or mechanical reference which Jevons worked out in great detail, was founded upon the antecedent researches of Boole. The processes, however, were presented by Jevons in such a fashion, the principles were so simplified and the capabilities of the method so ingeniously developed that his work has a secure place of its own alongside that of Boole. This is not the place for discussing the permanent worth of the new analysis of inference, but it may be said that hardly sufficient justice has yet been done to many of the speculations into which Jevons was naturally led in the development of his analysis. His treatment of the relations of logical and numerical quantity, and his attempt to deal with induction apart from all quasi metaphysical principles are bold and subtle contributions to logical theory and, in connection with his other work in this department they sufficiently establish his place as an original and thoughtful logician.

For philosophical speculation, in the wider sense, Jevons had little inclination, and possibly from the character of his intellect, little ability. Dealing with ultimate logical and economical questions he was often driven to the verge of inquiries such as fall under the designation of philosophy, to problems of the theory of knowledge and of ethics, but he never crossed the boundary, and indeed seemed somewhat impatient of the existence of a land beyond the formal relations of logical terms or the quantitative variations of pleasure and pain. This lack of interest in problems going to the root of logical and economical theory makes itself apparent in almost all his works, and probably, for many reasons, deprives them of some of their value. It is impossible to say, however, what genuine contribution to English philosophising might not heve been made had so original and well endowed a mind been spared longer to us.

\section{THE BRITISH ASSOCIATION}

ATHOUGH the numbers at the Southampton meeting have little exceeded I200, still so far as the essential work of the Association is concerned, it has been up to a fair average. The New Forest excursion was an especially enjoyable one, though that to the Isle of Wight was most interesting from a scientific point of view.

During the meeting the reception rooms and the rooms in which the Sections have met have been connected by telephones. In each room was a board on which were painted in a line the letters indicating the Sections. Below each letter there was space for a figure to be inserted to indicate the number of the paper in the day's programme that was under discussion; if it were No. 3 in Geology, the attendant there sent the number to the reception room. Here the attendant marked the board, and then sent the information to all the other Sections, so that it could be known in all the rooms what was the subject under discussion in each Section.

There was a sharp discussion on the question whether the Association should meet in Canada next year, seeing that Oxford has withdrawn its invitation, but the meeting decided on Southport, with Prof. Cayley as President. Canada (Montreal) was, however, selected for I884.

There is a very strong feeling that the vote of the General Committee binding the Association to go to Canada in 1884 , was not a representative one. The first vote taken was adverse to crossing the Atlantic, though it was felt that if this were done it would be specially desirable to do so while the Marquis of Lorne is President, as he has done much in founding the most important scientific institutions in Canada, and his tenure of office terminates next year. When Southport gained the majority the larger number of the Committee left the room, not being aware that the place of meeting for the following year, 1884 , was going also to be determined, and the supporters of the Canada invitation, led by an able tactician, Capt. Bedford Pim, secured an easy victory. It is worthy of note that the Members of the General Committee, who contributed to this result, with few exceptions, did not include Presidents and Secretaries of Sections, or indeed many of the working members of the Association, and it is therefore greatiy feared that should the proposed visit be made, the meeting will not be a representative one.

It is satisfactory to learn that the Council are taking steps to learn the real wishes of the Members, by asking every Sectional Committee to send up three or four representatives to constitute a committee to confer with the Council as to the means of carrying out the proposal, if found to be feasible. It is worthy of note that previous to the meeting at Southampton, the Council sent out a notice to the whole of the General Committee, inquiring their views on the subject, and that the replies obtained from a far larger portion of the Committee than that attending the meeting was distinctly adverse to leaving the British Isles. It was felt that the proposed departure would be unfair to Life Members, who had purchased a right to attend meetings in that area, and would prevent the greater number of sectional officers and working members from attending, their movements being controlled by considerations of time and expense.

The following is the list of grants voted for next year :-

\section{A-Mathematics and Physics}

Scott, Mr. R. H.-Synoptic Chart of Indian Ocean

Darwin, Mr. G. H.-Harmonic Analysis of Tidal Obser$\begin{array}{lllllllllll}\text { vations } & \ldots & \ldots & \ldots & \ldots & \ldots & \ldots & \ldots & \ldots & \ldots & \ldots\end{array}$ Brown, Crum-Meteorological Observations on Ben Nevis

\section{$B$ - Chemistry}

Tilden, Prof. W. A.-Investigating Isometric Naphthalene Derivatives

Odling, Prof.-Photographing the Uitra-Violet $\dddot{\text { Spark }}$ $\begin{array}{lllllllllll}\text { Spectra } & \ldots & \ldots & \ldots & \ldots & \ldots & \ldots & \ldots & \ldots & \ldots & \ldots\end{array}$ Pye-Smith, Dr.--Elimination of Nitrogen $\ldots . \quad \ldots \quad$...

$$
\text { C-Geology }
$$

Etheridge, Mr. R. - Earthquake Phenomena of Japan $\quad \ldots \quad 5^{\circ}$ Williamson, Prof. W. C.-Fossil Plants of Halifax... $\quad \ldots \quad 20$ Sorby, Dr. II. C.-British Fossil Polyzoa ... Etheridge, Mr. R.-Fossil Phyllopoda of the Palæozoic

Rocks
Hawkshaw, Sir John-Erosion of the Sea Crasts of England

Hull, Prof. E.-Circulation of Underground Waters $\quad \ldots$

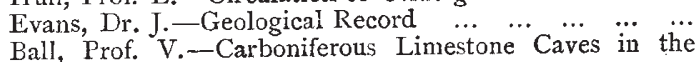

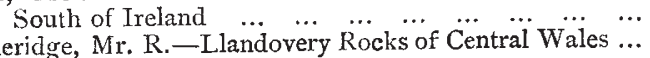
$65^{\circ}$ 50

\section{$D-B i o l o g y$}

Pitt-Rivers, General-Photographs of the Races and prin-

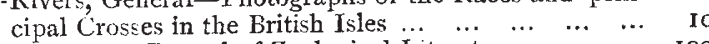
Stainton, Mr. - Record of Zoological Literature $\quad \ldots . . \quad \ldots \quad$ I00

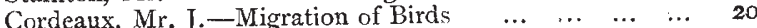
Lankester, Prof. Ray-Table at the Zoological Station at Naples

Pye-Smith, Dr.-Scottish Zoological Stations ... ....... Hooker, Sir J.-Exploring Kilimandjaro and the adjoining

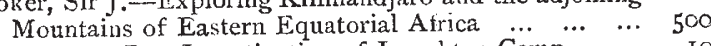
Meldola, Mr. R. - Investigation of Loughton Camp ... Io Sclater, Mr. P. L. - Natural History of Timor-Laut $\quad . .50$ 